\title{
CONDITIONS FOR MENTAL RESISTANCE IN DIFFICULT SITUATIONS
}

\begin{abstract}
The work environment is an integral part of the professional functioning of every employee (soldier) and is one of the most important areas of human activity - it is almost everyday life in the modern world.

The theoretical and empirical considerations taken in the study relate to the functioning of employees in stressful and dangerous professions and their mental resistance to difficult and extreme situations. The purpose of the article was to determine the basic factors conditioning mental resistance to difficult situations and factors that affect the successful implementation of the tasks. The research method adopted in the article was a qualitative analysis supported by the technique of defining real meanings.

The effect of the publication is the opportunity to learn effective methods of coping with stress and pressure, which determine how to respond to difficulties in both professional and private life.
\end{abstract}

Keywords: mental resilience, stress, professional development, professional professionalization, resilience.

\section{INTRODUCTION}

Coronaviruses have been off the beaten track of scientists' interest for several years. It was caused by the fact that they caused a mild cold which disappeared without any intervention within a few days. The current epidemic, caused by a previously unknown, highly infectious coronavirus species, has also contributed to the intensification of interest in the issue of human mental resistance to difficult and extreme situations.

Mental resistance is the ability to deal effectively with challenges, stress and pressure. As D. Strycharczyk and P. Clough "rightly point out, she describes how to respond to difficulties in both professional and private life. People who are strong and mentally resistant believe in their own skills, are open to new challenges and persistently pursue their goals" (Strycharczyk, Clough, 2017). What's more, they cope better with stressful situations, endure criticism and unfavorable remarks more easily, and use a possible failure for personal development. They also succeed more often. In connection with the above, developing mental resilience enables adequate use of possessed skills, and its proper measurement allows to plan appropriate support. Today, the model of mental

\footnotetext{
${ }^{1}$ Professor Grzegorz Rosłan, PhD, The Faculty of Management, Rzeszow University of Technology, 35-959 Rzeszów, al. Powstańców Warszawy 12; e-mail: g.roslan@prz.edu.pl. ORCID: 0000-0002-2566-5004.
} 
resilience and a questionnaire for its assessment are widely used, among others in business and healthcare.

\section{DEFINITION AND BASIC FACTORS CONDITIONING MENTAL RESILIENCE}

In the psychological literature there are several concepts related to the issues discussed in the article, used interchangeably: "mental resistance", "emotional resistance", "stress resistance", "tolerance to frustration". It should be emphasized that the term "mental resilience" is understood differently by the authors dealing with this issue. According to the author, among the many definitions of this term, notions formulated by M. Tyszkowa and M. Jarosz deserve attention.

According to M. Tyszkowa,

"mental resistance to difficult situations is a function of: a) the quality of orientation in a psychological situation; b) the motivational power of the goals of the activity; c) the capacity for emotional control and self-control; d) the state of shape, properties and internal coherence of cognitive structures that make up the personality; e) habits of responding to difficult situations and symptoms of emotional tension" (Tyszkowa, 1978).

This author pays special attention to the perceptual, conceptual and emotional function of the situation, where she assigns the basic role to the cognitive aspects of reflecting difficult situations, which determine both emotional excitation and - above all - the further development of emotion or its inhibition (Przetacznik-Gierowska, Tyszkowa, 2020).

In turn, M. Jarosz combines the term "mental resistance" with the concept of "psychological stress" and synonymous terms such as "stress", "stressor", "stressful situation", "frustration" and "conflict". It expresses the view that "stressor", "stressful situation" and "difficult situation" are unambiguous terms, the names of the factors causing stress, i.e. the state of stress. At the same time, he states that "of these terms" seems to be the most "difficult situation". This author distinguishes between mental resistance to stressor (difficult and stressful situation) and mental resistance to stress (stressful state) (Jarosz, 1988).

According to the author, resistance to stressor manifests itself in relatively low emotional reactivity to threats, obstacles and other factors specific to difficult situations. In other words, man perceives the situation in which he finds himself difficult, but he responds to this situation with a relatively weak emotional reaction, such as fear, anxiety or anger. Resistance to stress, on the other hand, is based on the ability to function properly, despite emotional excitement. This means that a person experiences emotional excitement, experiences fear, anxiety, anger or other emotional states of significant intensity, and at the same time acts consciously, effectively, controls his behavior and aims to achieve the chosen goal (Jarosz, 1988).

It is worth mentioning here that the concept of "emotional resilience" is defined in a similar way in the publication edited by J. Hildt: Ergonomics in the service of the army. By emotional immunity we understand the stability of mental and motor functions in the conditions of emotional interactions. In a broader aspect, it is the ability to manage your 
emotions, maintain high ability to work and perform complicated and dangerous activities without excessive tension, regardless of emotional impact (Hildt, 1972).

The quoted terms relatively broadly and comprehensively characterize the term 'psychological resistance'. The above-mentioned terms of mental resistance, to some extent, answer the question on what factors this resistance depends. However, it seems expedient, according to the author, to specify these factors more precisely. Therefore, to the basic factors that determine human mental resistance to difficult situations. should include: the properties of the nervous system and some personality traits of the human. On the properties of the nervous system - for example, the strength and persistence of emotions and the type of emotional response depend. People with an anxiety attitude when experiencing a difficult situation can experience and often experience strong anxiety that prevents them from working efficiently. In contrast, people who are characterized by confidence in their strength and attitude to overcome difficulties, less often experience difficult situations of emotional arousal disorganizing their actions (Talaga, Sikorska, Jawor, 2018). In close connection with the above properties, there are:

- adaptation to the conditions and requirements associated with the occupation or function performed,

- level of motivation to achieve the intended goal, hierarchy of values and needs, level of aspiration etc.,

- personality maturity; mature personality is characterized by, among others its content, subordination of aspirations and side needs to the leading aspiration and the ability to restrain emotions; these properties co-condition organized and efficient functioning in difficult situations; and on the contrary - one of the manifestations of immature personality is low resistance to stressful situations (Sikorska, 2017).

Particularly important factors conditioning mental resilience also include human cognitive structures, the level of professional preparation, and psychological readiness for professional activity. From these factors include depend on: the way people perceive difficulties, i.e. how they are perceived and how they see themselves in a difficult situation.

Due to the limited possibilities of this publication, only some of these factors will be presented below.

\section{ADAPTATION TO PROFESSIONAL CONDITIONS AND REQUIREMENTS AS WELL AS THE FUNCTION PERFORMED}

Adaptation - it is the adaptation of the human body and personality to changes in the environment or to changing living conditions and activities. The proper adaptation process is of great importance for shaping mental resilience to difficult situations. The positive course of adaptation is, among others on increasing the adequacy of human behavior in relation to the impact of the new environment. Adaptation creates opportunities for a more optimal functioning of the body and personality in unusual conditions. However, if adaptation does not occur, additional difficulties arise in mastering both the subject and the conditions of activity, including the occurrence of disturbances in its regulation (Aleksander, 2017).

Research results and literature analysis show that, depending on external conditions and the level at which human and environmental interactions are made, various types of 
adaptation can occur (Okoń, 2001): physiological - changes in the interaction of various physiological systems of the body, e.g. when increasing the intensity of work; biological changes in the metabolism and functions of organs - according to the vital importance of stimuli, e.g. when acclimatizing (when sleep is disturbed, appetite - work performance decreases); psychological - adaptation to the conditions and tasks at the level of processes and mental functions, e.g. increased sensitivity of the eyesight in the dark or dulling of auditory sensitivity under the influence of noise and strong sounds (sensual adaptation), an increase in the pace of thinking at a time deficit; social - implementation into a new job, into a new social environment, adaptation to a new place of life (Doroszewska, 1995; Koczniewska-Zagórska, Nowacki, Wiatrowski, Bandura, 1986).

These types of adaptations can be more or less manifested simultaneously. Such processes occur, for example, in the initial period of young people's work in industrial plants and other institutions, young soldiers (officers) in the army, etc. A model example of the adaptation process and related difficulties should be the course of adapting young soldiers (conscripts) to the requirements of the service military.

After crossing the barracks gates, in their life and operation, fundamental changes take place: a change in the environment, new discipline requirements, regulatory order of the day, etc. They are faced with requirements for mastering new messages, skills and habits, new regularities of behavior, new elements and forms of relations. interpersonal, etc. All changes and new requirements may cause some negative mental states among some soldiers, especially at the beginning of their service, thus causing specific adaptation difficulties. They result from both the specificity of military service and the individual personality traits of soldiers.

According to the practice and literature on the subject, the process of adapting young soldiers to military service has a different course. Depending on the period and properties of the adaptation process, soldiers can be divided into three groups. For a significant proportion of soldiers, the adaptation period lasts 2-3 weeks. They show no major adaptation difficulties. These soldiers achieve good results in combat preparation. For soldiers in the second group, the adaptation period is longer. They have adaptation difficulties, which are accompanied by deterioration of well-being, and reduction of physical and mental fitness. Soldiers of the third group have significant adaptation difficulties. They find, among others expression in mental disorders requiring treatment (Nowosielski, 2009).

Considering the above issues, which concern, among others soldiers (military commanders), the main subject of further considerations will be professional adaptation, which W. Szewczuk describes as the "process of adaptation of an employee starting work in a given profession to the requirements of the work environment; this kind of adaptation occurs in adult workers in the event of a change of profession ..." (Szewczuk, 1979).

Graduates of military schools and academies, commanders appointed to subsequent official positions, and professional soldiers appointed to perform many other responsible functions are also adapted to professional activity. The process of professional adaptation is accompanied by the process of social adaptation, which consists in adapting a person to specific living conditions and activities in a given environment. In further considerations, both these processes will be considered together.

In this sense, the process of professional and social adaptation includes: adaptation to professional requirements; to new working conditions; to the new social environment, its customs, norms and traditions. It should be particularly emphasized here, however, that 
the process of professional adaptation is not a passive act of subordination to professional requirements, but rather an active and creative involvement in professional activity. There are many general features specific to any adaptation process in professional adaptation. Therefore, it is a process that takes place thanks to energetic, psychological and moral mobilization of a person in accordance with professional and environmental requirements. The possibilities of such mobilization and mastering new tasks are different for individual people. Therefore, there are individual properties in the process of their adaptation in terms of time, relevance and accuracy (Kwiatkowski, 2003).

There are two groups of factors conditioning adaptation. The first group includes factors related to human personality traits. These are such properties as: general and special preparation, character, temperament, cognitive processes, functional states, age and others (Dang, Ian Nuberg, Bruwer, 2019). For example, people characterized by a slow response to external stimuli, calm, reasonable (phlegmatic) exhibit great difficulties in adapting to complicated living and operating conditions. However, their adaptation is more durable compared to people who react quickly and strongly to the environment, emotional, prone to frequent changes in general condition (spitfire, sanguine). The melancholic is even different. Under the same conditions, he experiences deeper complicated events, is inclined to increase difficulties, sees (and expects) something bad and dangerous in everything. New living conditions can make him completely lost.

The course and results of professional adaptation depend primarily on the level of readiness to complete tasks and motivation. At the same time, high prosocial motives, a sense of duty, responsibility, can to a certain extent compensate for the lack of experience, impact on the adaptation of unfavorable temperament traits, etc., because these motives favor the manifestation of activity and adequate functioning of mental processes, and on the contrary, the weakening of prosocial motivation leads to the breakup of valuable forms of adaptation.

The second group consists of such factors that exist objectively, e.g. measures that facilitate familiarization with the nature and working conditions, properties and examples of managers, social environment, educational work and others (Strelau, 2006).

Adaptation to new conditions is more efficient if initial work is carried out to familiarize man with possible situations in his activities. An important element of the preparatory work is the activation of pro-social behavior motives, maintaining a high level of cognitive activity, shaping missing skills and habits (Penuel, Fishman, Yamaguchi, Gallagher, 2007). In many social environments, especially in the army, great attention is paid to compliance with applicable standards of conduct. In this case, the basic role has to fulfill knowledge, which allows you to understand the essence of a given principle of conduct. Moreover, according to Z. Skorny,

"an internalized norm accepted by the entity is not treated as an order from outside, executed only to obtain a prize or to avoid punishment. It becomes an autonomous regulator functioning also when it is not subject to external control. (...) Acting in accordance with the standard is a source of internal satisfaction and a sense of well-fulfilled duty. However, violation of the norm causes a sense of guilt and loss of self-respect" (Skorny, 1989). 
Thus, the process of professional and social adaptation consists of several stages: cognitive; learning new patterns of activities, social norms and ways of behavior; psychological reorientation; developing habits and internal acceptance of new tasks and operating conditions.

At this point, it should be recalled that man has certain restrictions on adaptability, e.g. fatigue, hunger, thirst, etc. Relativity of adaptation also occurs in sensations: pain, temperature, vibration. It is almost impossible to adapt to very high and low temperatures, pain, etc. It is also worth mentioning that there is not enough data in the psychological literature regarding the answer to the question whether and to what extent it is possible to adapt to difficult situations. Literature in the field of aviation and space psychology is an exception. However, it applies to pilots and astronauts (astronauts), i.e. especially selected people (Terelak, 2017; Pokino, 1977).

It should be mentioned that the most common problems of resistance to stress are combined with the innate properties of the nervous system and the acquired skills of coping with stress (Heszen, 2013). At the core of a man's ability to cope with new, changing life situations is his general mental fitness, also called general ability or intelligence. The essence of these abilities is not only the ability to passively adapt to environmental conditions, but above all the possibility of purposeful activity that sets out various ways of dealing with stress. Coping with stress relies on a constantly changing cognitive and behavioral effort directed to specific external or internal requirements, which are assessed as burdensome or exceeding human abilities (Miedziun, Czabała, 2015).

Acquired coping skills include primarily professional training and experience. A good example would be adapting the remote control to difficult situations. It has been found that underlying this adaptation are two important psychological mechanisms. The first of them is associated with the process of flight training. It is based on the fact that as you gain practice, the degree of difficulty of aerial tasks decreases. The second psychological mechanism is to reduce sensitivity to stressors, by learning techniques to control your own emotional states (Baqutayan, 2015).

\section{PSYCHOLOGICAL READINESS FOR PROFESSIONAL ACTIVITY}

Another, extremely important factor conditioning mental resilience is the psychological readiness for professional activity or related to the function performed, including readiness to act in difficult situations. According to L.M. Popova, I.M. Puchkova and P.N. Usti, psychological readiness - Is an important premise for targeted activity, its regulation, stability and efficiency. It helps a man to successfully perform his duties, correctly use knowledge, experience and personal properties, maintain self-control and correct his actions during the emergence of unforeseen obstacles (Popov, Puchkova, Usti, 2016).

The authors distinguish two types of psychological readiness: permanent (general) and short-term (situational). Permanent readiness is a structure that includes:

- positive attitude to a specific type of professional activity,

- adequate to the requirements of the business, profession, character traits, temperament, ability and motivation,

- necessary knowledge, habits and skills, 
- professionally durable properties such as insights, attention, thinking and emotional processes.

Situational readiness - is updating, adopting all forces, creating psychological possibilities for effective performance of activities at a given moment. General and situational psychological readiness include the following components:

- motivational (interest in a given activity, the need for effective task performance, striving to succeed and show oneself from a better side),

- cognitive (understanding responsibilities and tasks, assessing their significance, knowledge of the means necessary to achieve the goal, imagining likely changes in the situation),

- emotional (sense of responsibility, faith in achieving success, focusing on the task, overcoming disturbing interactions, doubts, fear etc.).

It should be mentioned that difficult situations occurring in human activity are accompanied by specific states of psychological tension (stress). They are, among others caused by such circumstances as danger, novelty, the job of strength; physical obstacles weather, town, strong noise; failures of work equipment, equipment malfunction, interpersonal relationships; not enough experience etc. In other words: anything that hinders or frustrates achieving a goal. The impact of difficult situations on the course and result of action depends not only on the nature of the task and circumstances, but also on the individual characteristics of a person, motives of his behavior, experience, habits, basic properties of the nervous system, emotional resilience. In one person, psychological stress arises "easier" and lasts longer than another. In the same situation, the degree of psychological stress varies from person to person. Stress as a condition covers the whole psyche and affects the nature and level of mental activity as a whole and on individual mental functions. The literature on the subject distinguishes several forms of psychological stress: perceptive - occurring in the event of great difficulties and errors when receiving information; intellectual - when it is impossible to find a way to solve a task or exit a critical situation; emotional - associated with the emergence of emotional states disorganizing action, the inability to make conscious effort and self-control; motivational - binding min. fighting motives, e.g. continued active performance, duties or evasion of danger and risk. It is worth reminding that, in a state of psychological stress, primarily complex intellectual activities and processes are disorganized. However, simple operations are relatively resistant (Lojek, 2007).

An analysis of human behavior in emergency situations shows that the most powerful stimulus that leads to erroneous activities is incomplete information. In this situation, high psychological readiness becomes necessary, which can to a certain extent compensate for the lack of sufficient information. To achieve such psychological readiness, training methods are necessary that develop speed of thinking, suggest - how to use previous experience to successfully operate in conditions of incomplete information, shape the ability to switch from one attitude to another, to forecast and anticipate possible events (Czajkowski, 2010).

An important method of preventing excessive emotional tension is planning your activities, especially thinking through them carefully and carrying out imaginary "gameplay". It is also beneficial to develop possible variants of actions in situations that may arise at work - including emergency situations. A good illustration of the above recommendations for proper training is an example of working on himself the American 
supersonic aircraft flyer W. Bridgeman, who conducted his trainings in the cabin of the aircraft, and then supplemented them by recreating in his imagination all the details of the next summer.

In summary, these general considerations can be said that psychological readiness for difficult situations - these are active states of the body and personality that reflect the requirements of these situations and appear as a regulator of goal-oriented behavior. Psychological readiness is conducive to maintaining the efficiency of operations with unexpected complications and the formation of stress reactions.

\section{SHAPING PSYCHOLOGICAL READINESS FOR PROFESSIONAL ACTIVITY}

Business readiness develops and strengthens by equipping people with general and professional knowledge, skills and habits, and improving personality traits that are important in professional terms. It is worth mentioning that the motivational factor is extremely important. Awareness of the social and personal importance of work is conducive to raising readiness. At the same time, objectively favorable working conditions are necessary. According to experts, the targeted teaching process according to profiling disciplines is particularly important. This kind of teaching creates favorable conditions for the formation of ideas about future activities. And also about the nature of the workplace, specific working conditions and typical situations that occur in practice including difficult situations (Ryś, Trzęsowska-Greszta, 2018).

Moving on to the merits, in order to prepare a man for work in stressful situations, the following principles, methods and techniques of exercises and trainings are proposed: gradual introduction of an increase in the pace of activities; solving tasks with insufficient information, disturbances, occurrence of risk and threat elements; introducing unexpected obstacles and unexpected complications to classes; setting a task that requires independent selection of one of several possible ways to solve it; creating situations leading to partial setbacks and requiring increased activity in the future; setting a task and creating situations that require an immediate transition to bold, independent and organized activities; developing models of future activities depending on changes in their external and internal conditions and others (Heszen-Niejodek, 2007, Heszen-Niejodek, 2000).

No less important determinant of shaping psychological readiness is the preservation of the known teaching principle consisting in grading difficulties. Studies show that exercises aimed at overcoming negative mental states, preparation for risk and danger activities should be graded. At the same time, one should take into account the personality characteristics, knowledge and habits of a given person. Unauthorized optimistic mood can turn into fear and disbelief in your own abilities - in the event of failure (Heszen-Niejodek, 2000).

Permanent readiness is also shaped by physical exercises and sports, which develop mental resilience, speed and accuracy of reaction and attention. It follows that the main factors conditioning human mental resistance to difficult situations are shaped in the process of properly organized training and upbringing, including physical education and sport (Heszen-Niejodek, 2002).

However, special preparation and specialist experience play a special role in this respect. There is a lot of evidence that stress causes a much smaller reduction in performance in people who are better prepared in terms of work. The results of studies by 
many authors testify to the fact that functional patterns developed and thoroughly fixed in the human central nervous system, which are shaped on the basis of knowledge, especially skills and habits, are not disorganized under the influence of stress, age-related involutional changes and other adverse effects. for a man's situation (Heszen-Niejodek, 2002).

Shaping psychological readiness to perform a specific task remains closely related to the formation of general (permanent) readiness. The most important indicators of such readiness, which has already been mentioned, is the mobilization of mental processes to perform the task, personal properties, experience and concentration on the task and the way it is solved, as well as - focus on maximally rational and full use of forces to overcome difficulties and achieve positive result. These goals are possible to achieve through proper training and educational work. Among the multitude of objective and subjective factors on which the process of shaping and the level of readiness to perform a task depends, motivation should be distinguished. A task-oriented theme stimulates a person to be active, receive and remember information as required by the task (Moj, 2011).

The motives for behavior before performing a difficult task are complex and often ambivalent. It happens that a person experiences a fight of various motives and finds a reason to refrain from participating in the performance of a risk-related task with great difficulties. Scientific data shows that behavior can be polytotivative, i.e. stimulated by several motives. At the same time, the influence of different motives is not equal. The most important motif turns out to be for a man important subjective significance. It is therefore extremely important that a person treat a given task as personally significant. In this case, his attitude to the task is qualitatively different compared to the requirement to perform the task only out of necessity (Terelak, 1977).

A positive attitude to the task stimulates a deeper interest in it, strengthens cognitive activity, allows you to perform a large range of preparatory activities in a short time. The task itself is in this case a great stimulant, because it corresponds to the needs, interests and attitudes of personality. With a neutral or passive attitude to the task, a positive result can also be achieved, but the preparatory activities require so much effort that it has a negative impact on the level of psychological readiness (Terelak, 2001).

\section{CONCLUSION}

Psychological readiness to perform a specific task by the team leader (commander) is achieved through goal-oriented interaction, among others through:

- conducting appropriate educational undertakings,

- clarification of the task content and familiarization with the conditions and situation of future activities,

- proper organization of activities, exercises and trainings,

- activation of self-tuning for successful operation.

In conclusion, it should be emphasized that managers (commanders) should take into account other circumstances. First of all - one should not allow for fatigue. Strong physical and especially mental fatigue causes a weakening of perception, attention, memory and thinking. It can be the reason not only for errors in operation, improper use of technical devices, but also for inhibiting human psychological readiness for action. 
Secondly - the manager (commander) should pay special attention to young, less experienced people. It may be that after receiving the task, due to insufficient knowledge and experience, the young person is not able to mobilize himself properly to the requirements of the situation, because he underestimates the potential difficulties, he counts on the fact that success can be achieved without careful preparation.

Thirdly, it should also be taken into account that some professionally experienced people may experience inadequate self-mobilization after receiving the task. This happens as a result of overestimating one's own abilities, beliefs - that one is able to perform a given task without proper preparation. Such a commander (operator) usually does not confront his experience in the light of the new task. It makes no effort to develop the most optimal plan and better ways of doing things. Therefore, it is advisable to place more complicated tasks towards experienced specialists and entrust them with the obligation to help young people (soldiers).

It is also worth remembering that shaping and maintaining psychological readiness depends not only on managerial interactions, but also on the ability of a person to control his own readiness. Man is largely a self-regulating system. He is equipped with physiological and psychological mechanisms adapting him to the changing conditions of life and activity, self-management, mobilization of forces and experience, changes in the orientation and content of his activity.

\section{REFERENCES}

Aleksander, T. (2017). Pedagogiczne elementy adaptacji (kierowanej) społeczno-zawodowej nowych pracowników. „Annales Universitatis Mariae Curie-Skłodowska”, Sectio J, nr 2, vol. XXX/2017.

Baqutayan, Sh.M.S. (2015). Stress and Coping Mechanisms: A Historical Overview. "Mediterranean Journal of Social Sciences", No 2, Vol. 6.

Coping with stress, Heart and Stroke Foundation.

Czajkowski, Z. (2010). Lękliwość, lęk, obawa, strach i panika oraz odporność psychiczna zawodników. "Ruch dla Kultury”, Rocznik Naukowy nr 10.

Dang, H.L., Ian Nuberg, E.L., Bruwer, J. (2019). Factors influencing the adaptation of farmers inresponse to climate change: a review, Climate and Development.

Doroszewska, J. (1995). Pedagogika specjalna. Wrocław: Wydawnictwo Ossolineum.

Heszen, I. (2013). Psychologia stresu. Korzystne i niekorzystne skutki stresu życiowego. Warszawa: Wydawnictwo Naukowe PWN.

Heszen-Niejodek I. (1997). Styl radzenia sobie ze stresem: fakty i kontrowersje, „CZasopismo Psychologiczne", 3(1).

- (2000). Teoria stresu psychologicznego i radzenie sobie [w:] Strelau J., red. nauk, Psychologia. Podręcznik akademicki. Gdańsk: Gdańskie Wydawnictwo Psychologiczne.

(2000). Stres i radzenie sobie - główne kontrowersje [w:] Heszen-Niejodek, I., Ratajczak, Z., red. nauk., Człowiek $w$ sytuacji stresu. Problemy teoretyczne i metodologiczne, Katowice: Wydawnictwo Uniwersytetu Śląskiego.

— (2002). Teoretyczne i kliniczne problemy radzenia sobie ze stresem. Poznań: Stowarzyszenie Psychologia i Architektura.

Hildt, J. (red. nauk.) (1972). Ergonomia w stużbie wojska. Warszawa: Biblioteka Wiedzy Wojskowej. 
Jarosz, M. (1988). Psychologia lekarska. Warszawa: Państwowy Zakład Wydawnictw Lekarskich.

Koczniewska-Zagórska, L., Nowacki, T., Wiatrowski, Z., Bandura, L.R. (red. nauk.) (1986). Stownik pedagogiki pracy. Wrocław: Zakład Narodowy im. Ossolińskich.

Kwiatkowski S.M. (2003), Adaptacja zawodowa [w:] Pilch, T., red. nauk., Encyklopedia pedagogiczna XXI wieku, t. 1. Warszawa.

Łojek, W. (2007). Natura stresu. Spojrzenie z perspektywy ewolucyjnej. Kraków: Wydawnictwo Uniwersytetu Jagiellońskiego.

Miedziun, P., Czabała, J.Cz. (2015). Stress Management Techniques. "Archives of Psychiatry and Psychotherapy", No. 4.

Mój, A. (2011). Osobowościowe uwarunkowania nadziei na sukces wśród pilotów wojskowych oraz członków wojskowej obstugi naziemnej. „Polski Przegląd Medycyny i Psychologii Lotniczej”, nr 4, t. 17.

Nowosielski, W. (2009). Szeregowi dawniej i dziś [w:] Maciejewski, J., Krasowska-Marut, A., Rusak, A., red. nauk., Szeregowcy $w$ grupach dyspozycyjnych. Socjologiczna analiza zawodu i jego roli w społeczeństwie. Wrocław: Wydawnictwo Uniwersytetu Wrocławskiego.

Okoń, W. (2001). Stownik pedagogiczny. Warszawa: Wydawnictwo Naukowe PWN.

Penuel, W.R., Fishman, B.J., Yamaguchi, R., Gallagher, L.P. (2007). What Makes Professional Development Effective? Strategies That Foster Curriculum Implementation. "American Educational Research Journal", No 4, Vol. 44, December.

Pokino, P. (1977). Dobór i selekcja psychologiczna personelu latajacego i kierującego lotami [w:] Błoszczyński, R., red. nauk., Psychologia lotnicza. Warszawa: Wydawnictwo Ministerstwa Obrony Narodowej.

Popov, L.M., Puchkova, I. M., Usti, P.N. (2016). Formation of Psychological Readiness for Professional Activity: Competence Approach. "IEJME - Mathematics education", No 4, Vol. 11.

Przetacznik-Gierowska, M., Tyszkowa, M. (2020). Psychologia rozwoju człowieka. Tom 1. Warszawa: Wydawnictwo Naukowe PWN.

Ryś, M., Trzęsowska-Greszta, E. (2018). Kształtowanie się i rozwój odporności psychicznej. „Kwartalnik Naukowy”, nr 2(34).

Sikorska, I. (2017). Odporność psychiczna w ujęciu psychologii pozytywnej: edukacja i terapia przez przygodę. „Psychoterapia”, nr 2(181).

Skorny, Z. (1989). Mechanizmy regulacyjne ludzkiego działania. Warszawa.

Strelau, J. (2006). Psychologia różnic indywidualnych. Warszawa: Wydawnictwo Naukowe Scholar.

Strycharczyk, D., Clough, P. (2017). Odporność psychiczna. Strategie i narzędzia rozwoju. Gdańsk: Gdańskie Wydawnictwo Psychologiczne.

Szewczuk, W. (1979). Stownik psychologiczny. Warszawa.

Talaga, M.T., Sikorska, I.M., Jawor, M. (2018). Odporność psychiczna u osób z zaburzeniami afektywnymi i lękowymi a doświadczenia wczesnej traumy - badania pilotażowe. „Psychiatria Polska", No. 3(52).

Terelak, J. (1977). Zagadnienia osobowości $i$ motywacji w psychologii lotniczej [w:] Błoszczyński, R., red. nauk., Psychologia lotnicza. Warszawa: Wydawnictwo Ministerstwa Obrony Narodowej.

- (2001). Psychologia lotnicza [w:] Kowalski, W., red. nauk., Medycyna lotnicza. Wybrane zagadnienia. Warszawa: Wydawnictwo: Fundacja DOCEO. 
(2017). Characteristics of the scientific and implementational activities of aviation psychologists and scientific consultancy from the perspective of the 90 years of existence of The Military Institute of Aviation Medicine. "The Polish Journal of Aviation Medicine, Bioengineering and Psychology”, No 3-4(23).

Tyszkowa, M. (1978). Sytuacyjno-poznawcza koncepcja odporności psychicznej. „Przegląd Psychologiczny”, nr 1/tom XXI.

DOI: $10.7862 /$ rz.2020.mmr.8

The text was submitted to the editorial office: March 2020.

The text was accepted for publication: March 2020. 